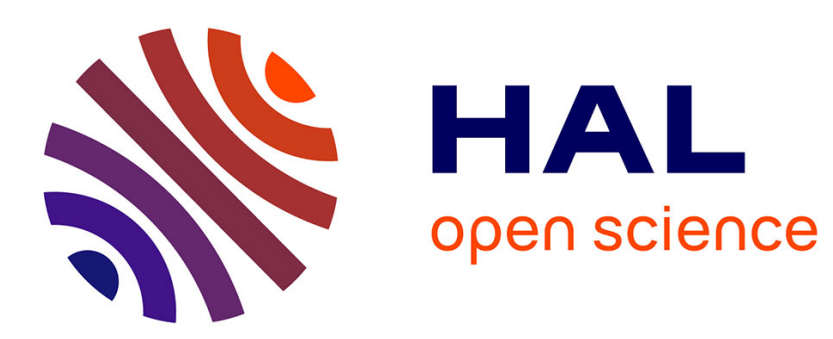

\title{
Protection of materials by advanced high temperature coatings
}

\author{
Roland Streiff
}

\section{To cite this version:}

Roland Streiff. Protection of materials by advanced high temperature coatings. Journal de Physique IV Proceedings, 1993, 03 (C9), pp.C9-17-C9-41. 10.1051/jp4:1993902 . jpa-00252332

\section{HAL Id: jpa-00252332 https://hal.science/jpa-00252332}

Submitted on 1 Jan 1993

HAL is a multi-disciplinary open access archive for the deposit and dissemination of scientific research documents, whether they are published or not. The documents may come from teaching and research institutions in France or abroad, or from public or private research centers.
L'archive ouverte pluridisciplinaire HAL, est destinée au dépôt et à la diffusion de documents scientifiques de niveau recherche, publiés ou non, émanant des établissements d'enseignement et de recherche français ou étrangers, des laboratoires publics ou privés. 


\title{
Protection of materials by advanced high temperature coatings $\left(^{*}\right)$
}

\author{
Roland Streiff
}

Université de Provence, 13331 Marseille, France

\begin{abstract}
Coatings are mandatory to protect hot components in turboengines and energy producing systems. The materials or alloys of these components are, indeed, subjected to a number of attacks which include oxidation, sulphidation, carburisation, chlorination, fluorination, hot corrosion by molten salt deposits and erosion/corrosion. Since 40 years a considerable number of coatings have been perfected to answer this problem. In this paper the wealth of available coatings and coating deposition processes are reviewed and a classification is proposed to shed some light in this maze of coatings.
\end{abstract}

\section{Introduction.}

A data bank has been created [1-2] the aim of which is to collect, organise, validate and deliver the existing information on the wide variety of available coatings which are currently in a research stage, in development, scaled up or in production. There are presently over 350 coatings collected in C\&HTC-DATA, the "Coatings and High Temperature Corrosion Data Bank", with different type, composition and application techniques. A survey of these coatings includes diffusion coatings, overlay coatings, intermetallic coatings, ceramic and thermal barrier coatings, which are applied by a range of processes such as single and duplex pack cementation, chemical vapour deposition (CVD), slurry, electroplating, electrophoresis, metalliding, electron-beam physical vapour deposition (EB-PVD), atmospheric plasma spraying (APS) and low pressure or vacuum plasma spraying (LLPS, VPS), detonation spraying (DGun) and high velocity flame spraying.

Figures 1 show data entry screens of the coating data base in C\&HTC data bank. The first screen presents the types of coatings which are collected in the data bank. This list includes aluminide coatings, modified aluminide coatings, chromium coatings, modified chromium coatings, silicide coatings, modified silicide coatings, overlay $\mathrm{MCrAl}$ coatings, ceramics coatings and thermal barrier coatings. These are general names of coating types which may include a family of coatings such as, for example, the modified aluminide coatings which are displayed in the second data bank screen. Modified aluminide coatings include chromium modified coatings, noble metals modified coatings, silicon modified coatings, yttrium modified coatings and other rare earth modified coatings.

If we add that these coatings are deposited by a number of deposition processes which are specific of the different classes of coatings - like for instance the aluminide coatings which may be applied by pack cementation, duplex pack cementation, pack codeposition, CVD vapour phase deposition, slurry, metalliding or hot dipping; or like overlay coatings deposited by

(*) Primary lecture. 

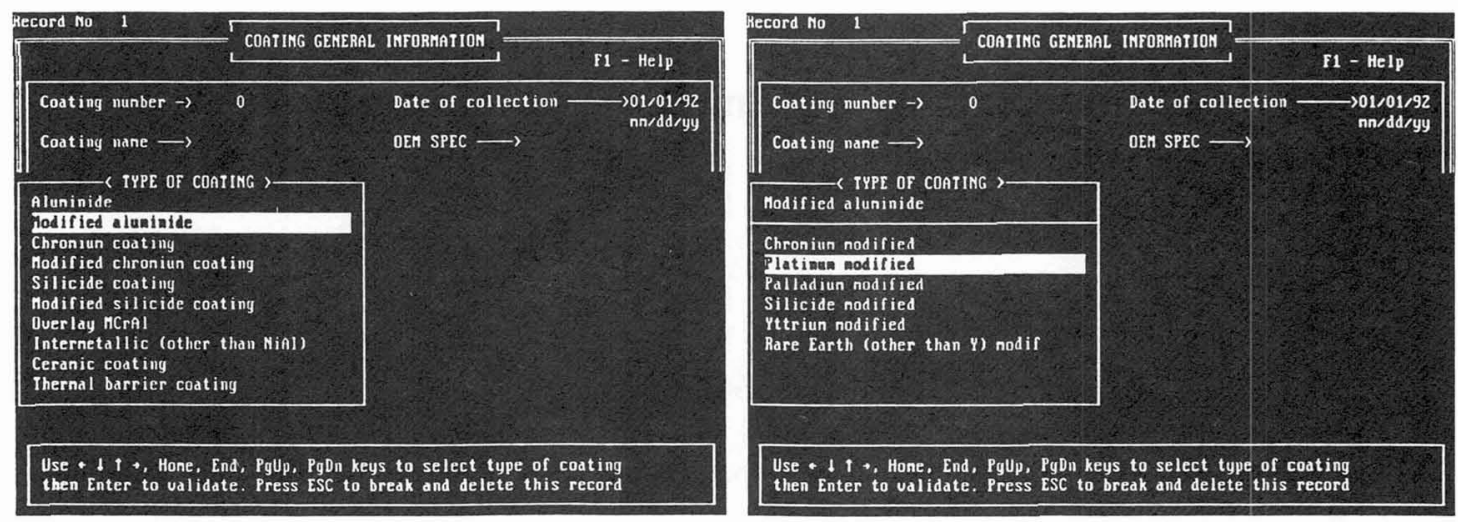

Fig. 1. - Data input screen of C\&HTC data bank displaying 1) the types of coatings to be collected (left screen); 2) the list of current modified aluminide coatings. (right screen).

simple physical vapour deposition processes (first screen in Fig. 2) or by a duplex deposition process such as C3A coating from SNECMA (second screen in Fig. 2) which is deposited by 1) electrophoretic deposition, 2) consolidated by a vapour phase aluminisation process - this demonstrates the complexity of the high temperature coating technology. C\&HTC has been created to bring some clarification in this maze of present day coatings. With respect to the status of the available coatings we propose a classification of the coatings as follows:

1) classical coatings, which include mainly diffusion coatings, like aluminides, silicides or chromium coatings deposited by pack cementation, slurry or hot dipping;

2) modern coatings, which include overlay coatings or thermal barrier coatings deposited by physical vapour deposition, EB-PVD or plasma spraying; and

3) advanced coatings, which include

- aluminide coatings deposited by a C.V.D. process;

- aluminide coatings modified either by noble metals, like platinum, palladium or platinum + chromium; or by the reactive elements like yttrium, hafnium or other rare earth elements such as cerium;

- complex overlay coatings deposited by duplex, or triple, deposition process with usually a first MCrAlX coating followed by consolidation processes;

- laser deposited coatings and laser remelted overlay coatings;

- intermetallic coatings, different from $\mathrm{NiAl}$, deposited on advanced materials and alloys, like aluminide coatings on titanium alloys or titanium aluminides or disilicide coatings on niobium or niobium based alloys;

- composite aluminide coatings, such as, for instance, nitride-, boron- or carbide aluminide coatings for titanium;

- etc.

This list of coatings, which indeed looks like a "pot pourri", is neither complete nor closed. This demonstrates that protection by coatings is a big issue for materials used at high temperature.

In this paper we will discuss two issues: the need for coatings and how to protect the materials. Answer to these questions involves high temperature protective coatings. This paper will therefore review the state of the art of coating technology. However, according to the long list of presently available coatings it will focus on a limited number of specific coatings 

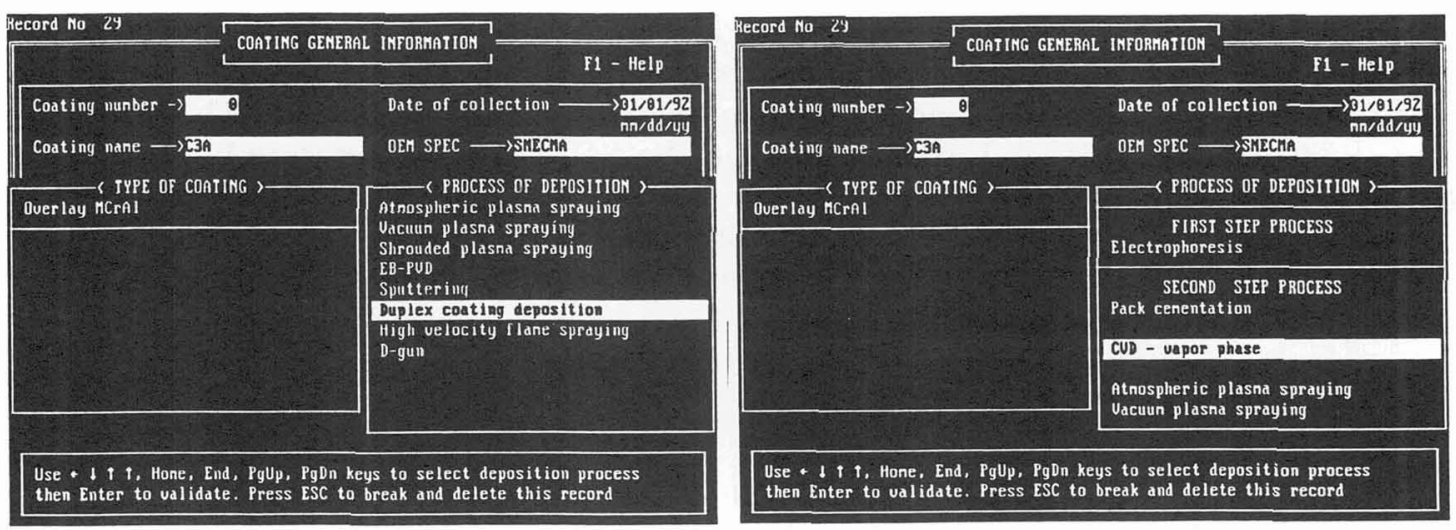

Fig. 2. - Data input screen of C\&HTC data bank displaying 1) the deposition processes of overlay coatings (left screen); 2) the two steps of duplex processing for C3A SNECMA coating (right screen).

in each of the above mentioned classes with emphasise on some advanced coatings; such as modified aluminide coatings, composite MCrAlY coatings, titanium aluminide coatings and composite coatings for titanium alloys.

\section{The need for coatings.}

The development of coatings arose from the answer to two questions: WHY protect materials and alloys at high temperature; and HOW to protect materials and alloys at high temperature.

2.1 WHY USE COATINGS. - The trend in modern energy-conversion systems and turboengines is toward a continuous increase in turbine inlet temperatures. Increasing the inlet temperature of a gas turbine from 900 to $1250^{\circ} \mathrm{C}$ can result in a $30 \%$ increase in the energy output of that turbine, fuel consumption remaining equal. Turbine inlet temperatures have risen by 6 to $9^{\circ} \mathrm{C}$ per year over the last 40 years thanks, in part, to improvements in the mechanical properties of alloys and in their resistance to corrosion. In today's energyconversion systems, a production unit is required to be reliable over very long periods of time - commonly 100,000 hours - and to burn lower grade fuel in order to keep consumption costs low. This increase in the operating temperatures of gas turbines coupled with the decrease in fuel and environmental quality and decrease in inherent superalloy corrosion resistance due to the search for improved mechanical properties, has led to the use of coating systems to protect hot section components [3].

The development of coating technology stems from, and is determined by, the progress of knowledge on high temperature corrosion [4]. Hot components of gas turbines and energy systems operating in aggressive environments are subjected to a number of mode of attacks termed collectively high temperature corrosion, which include oxidation, sulphidising, carburising, chlorination, erosion and hot corrosion induced by molten salts. The use of protective coatings has been an answer to remedy the lack of high temperature surface stability of metals and alloys in harsh environments.

It is now currently accepted that protective coatings on $\mathrm{Ni}$ or Co base superalloys encounter 
two types of high temperature corrosion degradation [5]. High temperature hot corrosion (HTHC), also designated as Type $1 \mathrm{HC}$, occurs at higher temperatures, typically in the 800 to $950{ }^{\circ} \mathrm{C}$ range. It is caused by molten salt deposition on the coating surface. The primarily active constituent of this salt is sodium sulphate $\mathrm{Na}_{2} \mathrm{SO}_{4}$. Low temperature hot corrosion (LTHC), also known as Type $2 \mathrm{HC}$, occurs in the $650-750^{\circ} \mathrm{C}$ range. The low temperature hot corrosion mechanism involves acidic fluxing of protective oxides by sulphur trioxide $\left(\mathrm{SO}_{3}\right)$ dissolved in molten sulphates. Figure 3 presents the corrosion rate versus temperature in the propagation stage of coating corrosion.

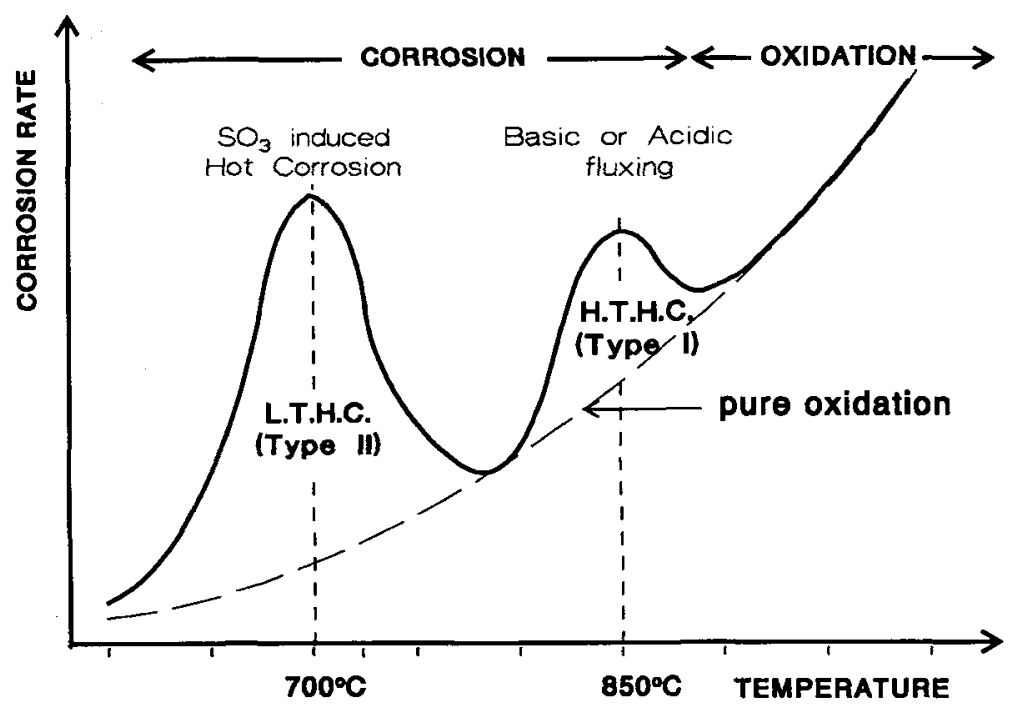

Fig. 3. - Corrosion rate versus temperature (from P. Steinmetz; Université de Nancy Fr - personal communication).

2.2 How TO COAT. - It is usually admitted that a protective coating must meet the following requirements:

- it must develop a protective oxide scale which should be free of defects, as covering as possible, i.e. without grain boundaries, and with a slow thickening rate;

- it must form a compact barrier between the substrate to be protected and the environment;

- it must have good adherence to the substrate, and should be free of flaws, pores or other defects which may offer a path to oxygen penetration or other aggressive gases; and in particular

- it should have rounded edges;

- it should be tailored to have a good compatibility with the thermomechanical properties of the substrate alloy;

- and, especially for coatings used in gas turbines, it should have a very smooth surface, thus result in low fuel consumption.

Following these requirements all current high temperature coatings are designed to form protective alumina, silica or chromia scales. 


\section{Diffusion coatings : the class of classical coatings.}

In 1971, Goward and Boone published a paper in "Oxidation of metals" [6] which became a landmark in the field of high temperature corrosion resistant coating technology. In this paper they established the mechanisms of the growth of aluminide coatings on nickel base superalloys. The reason why this paper is one of the most, if not the most quoted paper in the coating literature lies not only in the fact that aluminide coatings were the first, and still are the most used coatings, but also in that, it defined the general rules governing the growth of the diffusion class of coatings. Two basic mechanisms typify the diffusion coatings depending on whether the main diffusing species is aluminium diffusing from the coating media or is the base metal diffusing from the substrate alloy. This results in two types of coatings known as inward and outward types which will be described later on.

High temperature coatings based on intermetallic compounds such as aluminides or silicides are extensively used to protect gas turbine hot section components from attack in aggressive environments. The protective character of these coatings stems from the protective nature of the $\mathrm{Al}_{2} \mathrm{O}_{3}$ and $\mathrm{SiO}_{2}$ scales formed respectively on the aluminides or silicides at elevated temperatures. These coatings are usually produced by pack cementation or by chemical vapour deposition (GVD) which involve the diffusion of a predominant element such as aluminium or silicon resulting in what is known as "diffusion coatings". Diffusion coatings include mainly aluminides, silicides and to a lesser extent chromium coatings.

\subsection{PROCESSING OF DIFFUSION COATINGS.}

3.1.1 Pack cementation. - Pack cementation is one of the first processes used to produce diffusion coatings. During pack aluminising, the substrate to be coated is thoroughly cleaned, dried and then placed in an air-tight retort containing a mixture of aluminium (or an aluminium alloy), a halide activator $\left(\mathrm{NH}_{4} \mathrm{Cl}\right.$ or $\mathrm{NaCl}$ or $\left.\mathrm{CrF}_{2}\right)$ and an inert filler such as aluminium oxide. Figure 4 presents the schematic of a classical cementation box. This cementation box is then heated to promote the diffusion process at temperatures ranging from 750 to $1000{ }^{\circ} \mathrm{C}$ for 2 to 24 hours. The halide activator decomposes, the halogen reacts with the aluminium or aluminium alloys to form aluminium halides. The aluminium halide vapour diffuses towards the surface of the substrate and dissociates, releasing halide ions to further react with the aluminium powder in the pack.

The deposit on the surface of the part to be coated diffuses into the substrate to form a zone, the thickness of which is a function of time and temperature of the treatment. New phases or solid solutions are formed in the coating zone. The final microstructure of the coating is controlled by the substrate composition, temperature and the pack aluminium activity.

3.1.2 Chemical vapour deposition. - The chemical vapour deposition process can be described as quite similar to the pack cementation process except that the substrate to be coated is not in contact with the powder mixture. The gaseous transporting agent generated in the coating chamber can reach the surfaces of intricate shapes and holes or passages which are inaccessible to powder mixture in the pack cementation process. This process has been scaled up and an industrial process has been developed by SNECMA in France [7]. Figure 5 presents a schematic of the processing box used in SNECMA SVPA (Snecma vapour phase aluminising) process.

Advantages of the CVD aluminising process include the re-use of the pack cement, ease in masking the areas of the part that do not need to be coated and absence of any surface contamination by pack particles. 


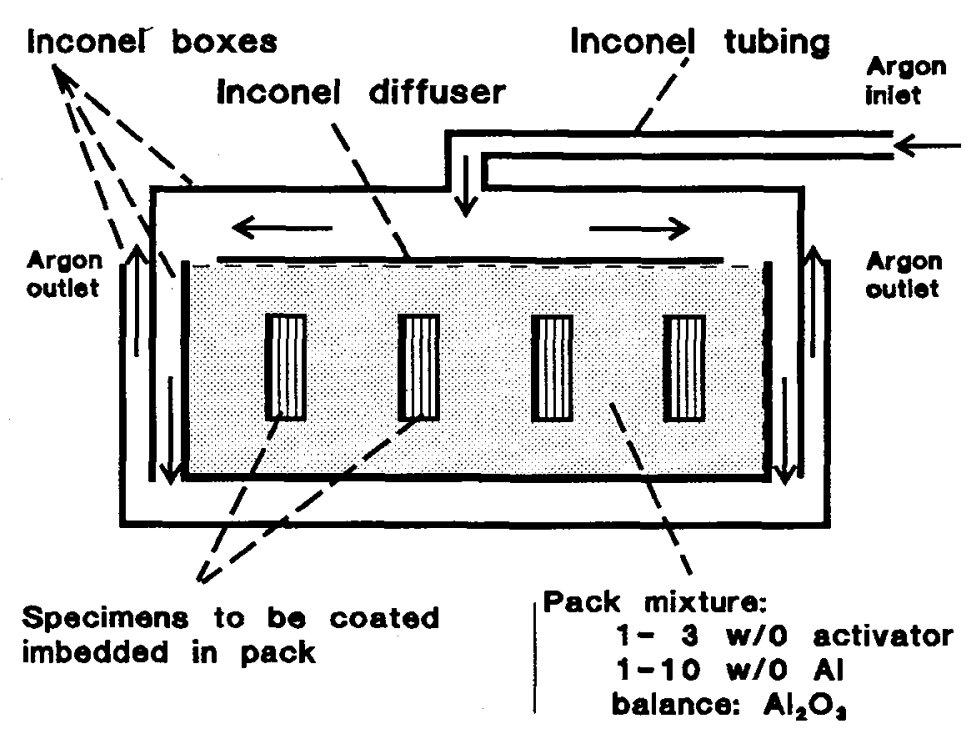

Fig. 4. - Schematic of a classical cementation box.

3.1.3 Slurry process. - Slurry coatings are obtained by applying a powder mixture of aluminium or an aluminium alloy plus an activator along with a binder either by spraying or brushing, which is then submitted to diffusion heat treatment at temperatures usually in the 1000 to $1200{ }^{\circ} \mathrm{C}$ range. If the slurry has a high aluminium content, an inward type coating obtains, otherwise a low activity outward type coating is achieved [8]. Figure 6 presents the microstructure of slurry aluminide coatings formed in an Al-rich slurry, respectively on a nickel base and a cobalt base superalloy.

Although the slurry process offers the possibility to easily add reactive elements in the slurry and so form modified coatings, there have been only few attempts to form modified aluminide coatings by this process. $\mathrm{YCrAl}$ and $\mathrm{CeCrAl}$ coatings were applied on nickel base superalloys and showed improved oxidation resistance [9]. More recently, Wu's group has performed an yttrium modified aluminide coating by first a slurry yttrising step followed by a pack cementation [10], which showed a great improvement in hot corrosion resistance because of improved adherence of the formed oxide scale.

3.1.4 Hot dipping. - This process, similar to the slurry process, involves immersion of the part to be coated in a molten metal pool to form an intermetallic coating by interaction with the substrate. Solid state diffusion may take place during dipping or during a subsequent heat treatment. Hot dipping of iron and iron base alloys have received the widest attention. It has been observed that hot dipping of iron in $\mathrm{Al}-\mathrm{Zn}$ alloys results in the formation of $\mathrm{Fe}_{2} \mathrm{Al}_{5}$ coatings on the surface, whereas under typical galvanising conditions, $\mathrm{FeAl}_{3}$ and $\mathrm{Fe}_{2} \mathrm{Al}_{5}$ layers can be produced [11]. A more recent hot-dip aluminising technique developed to improve oxidation resistance by coating low-carbon steels in a pure $\mathrm{Al}$ bath or in a bath with an $\mathrm{Al}-\mathrm{Si}$ melt, also has demonstrated that only an $\mathrm{Fe}_{2} \mathrm{Al}_{5}$ layer is formed whereas three intermetallic phases $\left(\mathrm{FeAl}_{2}, \mathrm{Fe}_{2} \mathrm{Al}_{5}\right.$ and $\left.\mathrm{FeAl}_{3}\right)$ exist in the $\mathrm{Fe}-\mathrm{Al}$ system [12]. 

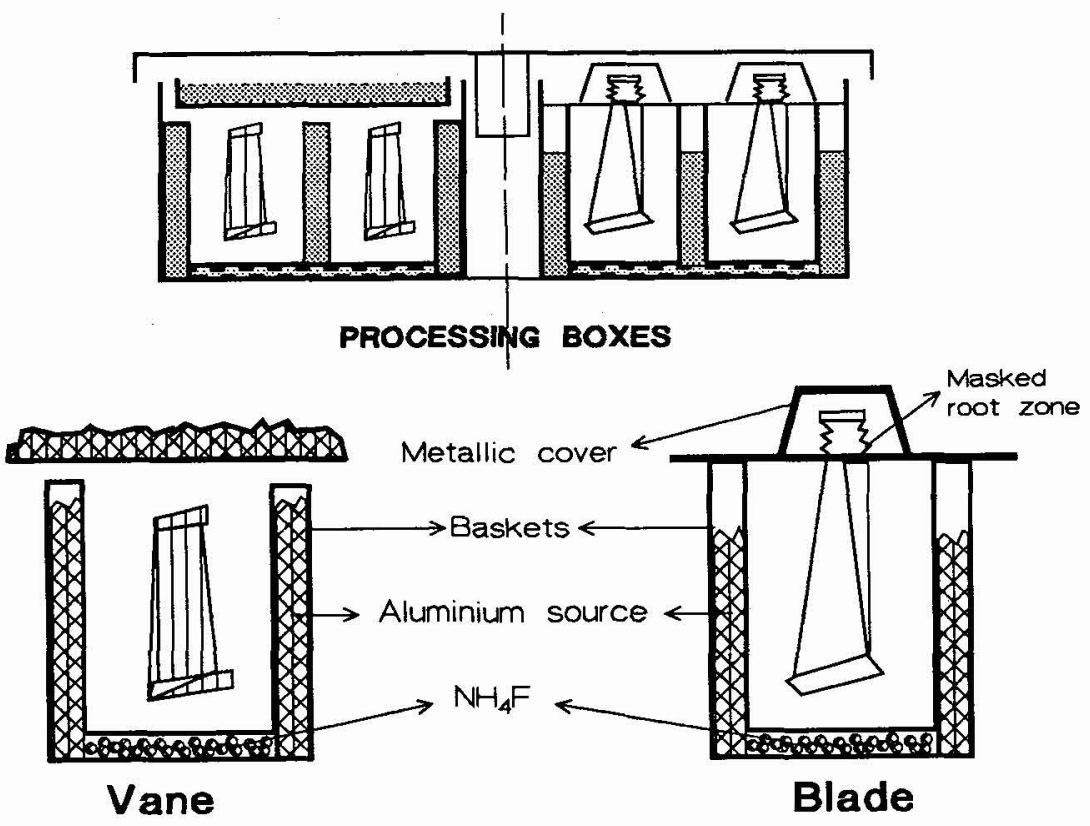

Fig. 5. - Schematic of the SNECMA SVPA (Snecma vapour phase aluminising) processing box.

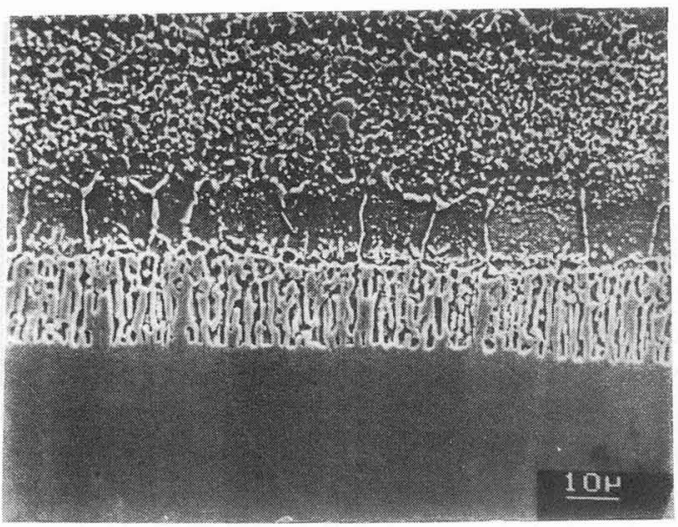

a)

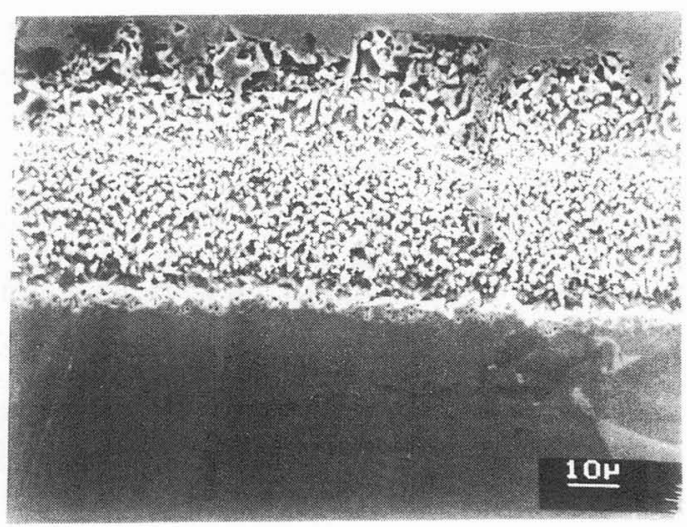

b)

Fig. 6. - Microstructure of Al-rich slurry coatings on a) a nickel base superalloy; b) a cobalt base superalloy. (by courtesy of P.C. Paitnak; Hawker Siddeley Canada Inc.). 


\subsection{AlUMINIDE COATINGS FOR NICKEL AND COBALT BASE SUPERALLOYS.}

3.2.1 Coatings for nickel base alloys. - Two diffusional growth mechanisms typify the pack aluminising process of nickel base superalloys depending on aluminium activity in the pack [6]. This gives rise to two coating structures.

- Low activity aluminide coatings, which grow by predominant outward diffusion of nickel, and present the archetypal two-zone structure. The outer zone is a phase-pure NiAl layer saturated with alloying elements which diffuse outwardly from the substrate concurrently with the nickel. The content of any foreign element in this layer is limited by its solubility in NiAl. For instance low activity aluminising of a graded chromium enriched alloy leaves the chromium confined in an underlying layer of the chromaluminide coating.

High activity aluminide coatings, which grow by inward diffusion of aluminium resulting in the formation of a $\mathrm{Ni}_{2} \mathrm{Al}_{3}$ layer. In the as formed conditions these coatings are typified by a single diffusion layer. Since the coating is formed by predominantly inward aluminium diffusion, substrate structure (and chemistry) is reproduced in the coating, with all the alloy elements being diluted in proportion to the amount of aluminium introduced. Thus the additional element content of this coating could be $60 \%$ of that in the original substrate. High activity coatings are subjected to a diffusion heat treatment to convert the initial $\mathrm{Ni}_{2} \mathrm{Al}_{3}$ layer into a more ductile and less oxidisable NiAl coating. During this transformation, aluminium diffuses inwardly from the $\mathrm{Ni}_{2} \mathrm{Al}_{3}$ to meet and react with the nickel diffusing from the substrate. This gives rise to the single-phase NiAl middle zone of the archetypal three-zone structure of the inward-high activity type aluminide coating. The inner zone is created by the outward diffusion of the nickel from the substrate like the diffusion zone in the low activity coating. After the diffusion treatment the outer zone of the coating consists in a $\mathrm{NiAl}$ matrix saturated with the alloying elements and containing numerous precipitates due to the lower solubility in the NiAl phase of these substrate elements. Figure 7 presents the microstructures of both a low activity outward type coating and a high activity inward type coating, as coated and diffused, deposited on an IN 738 nickel base superalloy.

3.2.2 Coatings for cobalt base alloys. - Common cobalt base superalloys do not contain aluminium, but 20 to $30 \mathrm{wt} . \%$ chromium and 5 to $10 \mathrm{wt}$.\% tungsten. Their carbon content is usually in the range 0.5 to $0.6 \mathrm{wt} . \%$. Cobalt base superalloys are protected by a $\beta$ CoAl coating which is usually formed by a low activity pack cementation process, the cobalt diffusing outwardly in the growing layer. The aluminising temperature is generally $50^{\circ} \mathrm{C}$ higher than the temperature for aluminising of nickel base superalloys. The morphology of the coating is quite different from the morphology of a coating formed on nickel base alloys. The coating does not contain an inner zone and the initial surface of the coated part is located near the $\mathrm{CoAl} /$ substrate interface. The diffusion of cobalt in the CoAl layer modifies the composition of the subjacent alloy which gives rise to the precipitation of tungsten and tungsten-chromium carbides at the interface. These carbides are usually formed as a continuous layer which can limit the cobalt diffusion from substrate alloy into the coating. Moreover, these CoAl coatings are more brittle and have a brittle-to-ductile transition temperature of about $250{ }^{\circ} \mathrm{C}$ higher than the NiAl coatings formed on nickel base superalloys.

Owing to the outward diffusion of cobalt, aluminide coatings on cobalt base superalloys usually present inclusion of particles from pack throughout the coating layer. This can be avoided by using a vapour phase or CVD process. Figure 8 presents the microstructure of a 


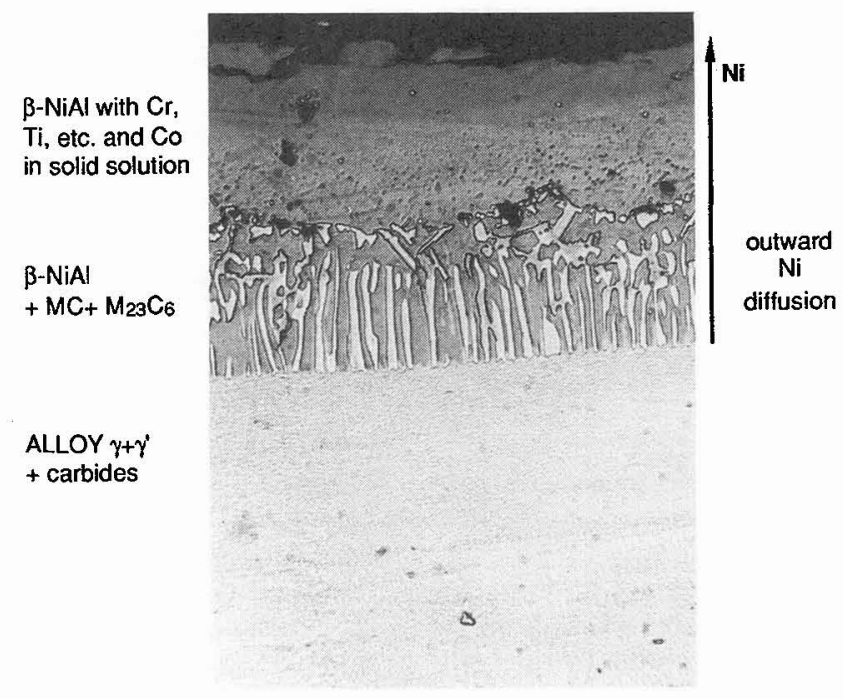

a)

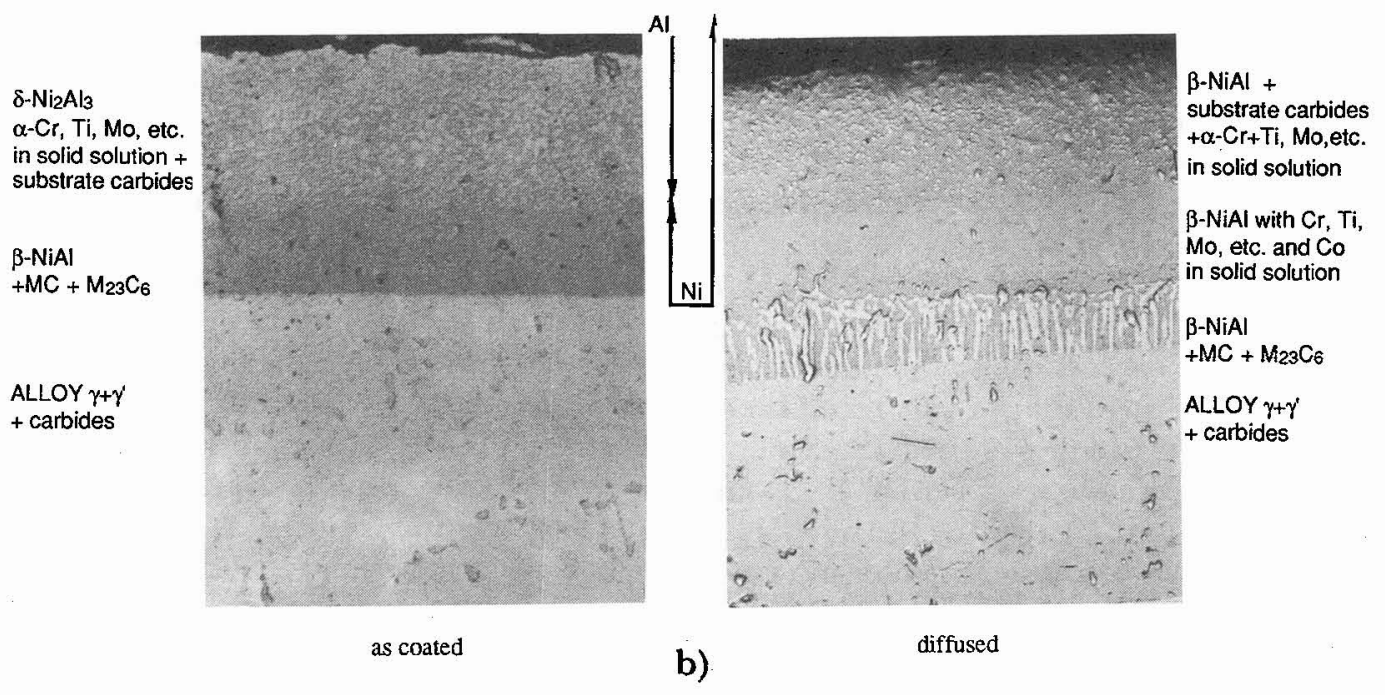

Fig. 7. - Microstructure of aluminide coatings formed on an IN738 nickel base superalloy: a) low activity outward type; b) high activity inward type, as coated and diffused.

pack aluminide coating deposited on a MAR-M-509 cobalt base alloy. This micrograph shows the pack particles entrapped in the coating.

3.3 ALUMINIDE COATINGS FOR IRON BASE ALLOYS. - Although there have been a certain number of investigations on aluminising of iron base alloys, like low carbon iron or 304 Stainless steel, which demonstrated an improvement in oxidation resistance, basic research in iron pack aluminising has received, for a long time, only little attention. In 1984, Bangaru and Krutenat [13] published one of the first attempt to protect 316,310 and $1800 \mathrm{H}$ stainless steel 


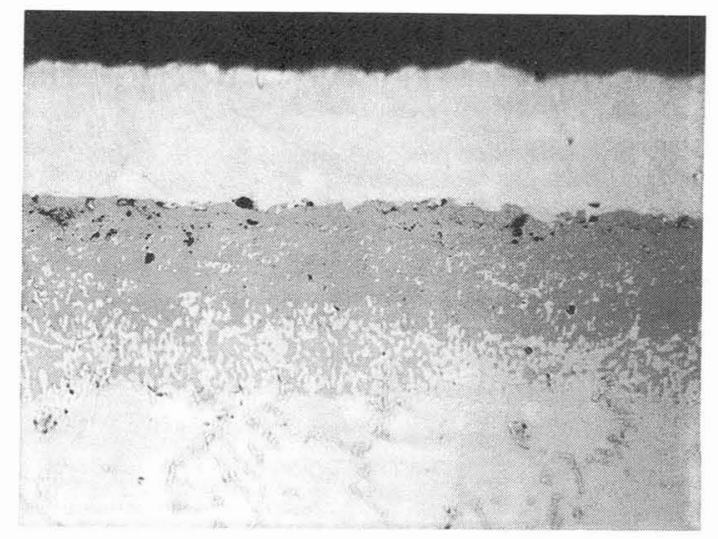

Fig. 8. - Microstructure of a pack aluminide coating deposited on a MAR-M-509 cobalt base alloy (by courtesy of G.W. Goward; Turbine Components Corporation, USA). The thick outer part of this micrograph is a nickel plate necessitated by the brittleness of CoAl.

with a low activity pack aluminide coating. They observed that in all the diffusion aluminised alloys, two distinct layers form : an outer aluminide layer and an inner interdiffusion layer. The interdiffusion layer involves "ferritisation" of the substrate, a process akin to perlitic transformation in carbon steel. This layer demonstrated high hardness with good mechanical integrity and with a thermal stability which depends strongly on the ease of ferritisation of the substrate. This type of coating has been used in the petroleum and chemical industry and has shown good corrosion resistance. Especially, the interdiffusion layer seems to be responsible of the good integrity of the coating. It was observed that in some case the interdiffusion layer beneath the outer aluminide is intact while the aluminide exhibits severe cracking which extends up to the interface with the interdiffusion layer.

Kung and Rapp [14] have only recently contributed to a better understanding of the thermodynamics and kinetics of the pack cementation process to produce aluminide coatings on pure iron. Furthermore, an FeAl pack coating produced at Ohio State University was examined as an alternative to raising the bulk aluminium concentration of an $\mathrm{Fe}_{3} \mathrm{Al}-5 \mathrm{Cr}$ subjected to corrosion in an oxidising/sulphidising environment [15]. It was found that the presence of the $\mathrm{Fe}-50 \mathrm{Al}$ surface layer on the $\mathrm{Fe}_{3} \mathrm{Al}-5 \mathrm{Cr}$ reduced the weight gains to the low level measured for the pure binary Fe-28Al.

3.4 LimitaTIONS OF ALUMINIDE COATINGS. - Diffusion aluminide coatings deposited by pack cementation, were the first coatings used to improve the oxidation resistance of Udimet 700 and B 1900 first stage blades in aircraft gas turbines. These coatings resulted in marked improvement in oxidation resistance of turbine hot section vanes and blades. But in turboengines running with lower grade fuel and in harsh environments such as the marine environment, the simple aluminides suffer hot corrosion attack caused by the presence of impurities in the combustion gases. In particular the discovery of type II low temperature hot corrosion has revealed that the degradation rate of protective coatings may be much greater in the lower range of operating temperatures. Moreover, the use of substrate alloys containing less chromium and more second phases such as carbides or oxide dispersions involves a loss in the protectivity and durability of these coatings. This has prompted the development of the MCrAlY overlay class of coatings designed to provide a protection system whose 
main characteristic is that its composition is independent from the substrate and is optimised to provide hot corrosion resistance and in some instances improved mechanical properties such as thermal fatigue resistance. However, a number of modified aluminide coatings have been developed to remedy this drawback of aluminide coatings and to provide an economic alternative to the very expensive PVD processes. Some of these will be reviewed in the section on advanced coatings.

\section{Overlay coatings: the class of modern coatings.}

4.1 LOW PRESSURE PLASMA SPRAYING COATINGS. - Early interest in overlay coatings was focused on several cobalt based CoCrAlY's with 20-40 wt.\% $\mathrm{Cr}, 12-20 \mathrm{wt} . \% \mathrm{Al}$ and $0.5 \mathrm{wt} . \%$ $Y$ produced by the EB-PVD process. Such coatings have been found to provide much better resistance to type I hot corrosion compared to the NiCrAlYs which are suitable for protection against type II hot corrosion. However, high $\mathrm{Cr}$ low Al containing CoCrAlY coatings are also known to be resistant to type II hot corrosion attack around $675^{\circ} \mathrm{C}-775^{\circ} \mathrm{C}$.

Until about 1980 all MCrAlY coatings were applied by electron beam vapour deposition, but vacuum plasma spraying (or low pressure plasma spraying) has challenged this process and has became the most sophisticated coating technology. With the development of automated computer controlled spraying stations, this technology seems to have reached a point where only little improvement can be expected in the future. As a proof of this situation we may point out that at the 2nd International Symposium on High Temperature Corrosion (Les Embiez 1986), no paper was submitted on the technology of vacuum plasma spraying. What is most needed now for overlay coatings is a better understanding of the interdiffusion effect between coatings and substrate superalloys, and of the influence of the coating on the mechanical properties of the coated system.

The microstructure of overlay MCrAlY coatings consists of a two phase structure containing a fine dispersion of $\mathrm{Co}$ or $\mathrm{Ni}$ aluminide in a $\mathrm{Cr}$ rich matrix as shown in figure 9 which is a NiCoCrAlY coating deposited by vacuum plasma spraying, on a typical Ni base superalloy.

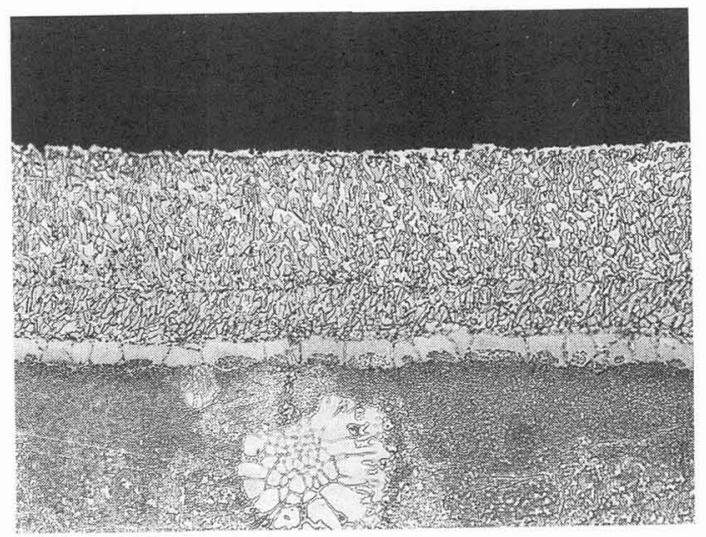

Fig. 9. - Microstructure of a NiCoCrAlY coating deposited by vacuum plasma spraying on a typical nickel base superalloy (by courtesy of G.W. Goward; Turbine Components Corporation, USA). 
Table I. - List of commercially available overlay coatings for hot corrosion resistance collected in CछHTC data bank (*).

Designation

\section{AIRCO TEMESCAL}

ATD-1
ATD-2
ATD-2B
ATD-2C
ATD-4
ATD-6
ATD-6B
ATD-6C
ATD-6D
ATD-12
ATD-14
ATD-18
ATD-30
ATD-41
ATD-42
ATD-63

ATD-70

ATD-71

\section{CHROMALLOY}

RT-30
$R T-31$
$R T-32$
$R T-34$
$R T-35$
$R T-36$
$R T-100$
RT-118
RT-119
RT-122
RT-141

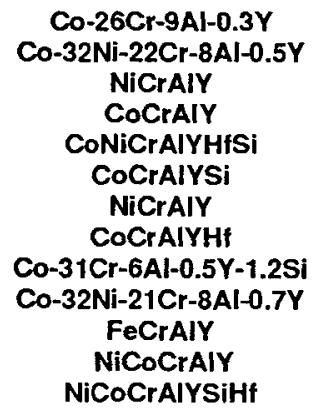

\section{PLASMA TECHNICS}

PT-103
PT-108
PT-112
PT-114

$\mathrm{Ni}-368 \mathrm{Cr}-11 \mathrm{Al}-0.25 \mathrm{Y}$

Co-25Cr-12.5AI-0.35Y

Co-21Cr-10AI-0.3Y

Co-23Cr-12Al-0.3Y

Co-22Cr-13.5Al-0.3Y

Co-18Cr-9Al-0.3Y

Co-18.5Cr-7AI-0.3Y

Co-18.5Cr-7.5Al-0.3Y

Co-18.5Cr-8Al-0.3Y

Co-31Cr-5Al-0.3Y

Co-25Cr-11Al

Co-26Cr-10Al

Co-17Cr-8AI-0.3Y

Co-21Cr-10Al-0.3Y

Co-30Cr-10Al-0.3Y

Co-35Cr-10Al-0.3Y
Application Process

Type of Protection
Co-28Cr-12Al-0.3Y

Ni-33Co-28Cr-8AJ-0.3Y

Type $\|$

Type I

Type I

Type I

Type I

Type I

Type 1

Type I

Type I

Types I and II

Type II

Types I and II

Types I and II

Type I

Type 1

Type II

resistant to cycling

Types I and II

Type II

\section{EB PVD \\ EB PVD \\ EB PVD \\ EB PVD \\ EB PVD \\ EB PVD \\ LPPS \\ LPPS \\ LPPS \\ LPPS \\ LPPS \\ LPPS \\ LPPS}

APS

APS, VP

APS, VP

APS, VPS

Ni-Cr-Si-B

Ni-17Cr-6Al-0.5Y

MCrAIY

Co-23Cr-13Al-0.65Y

$\mathrm{Ni}-23 \mathrm{Co}-17 \mathrm{Cr}-12 \mathrm{Al}$

NiCrAIY

50Cr3C2/50 NiCrAlY

50Cr3C2/50 CoCrAlY
50Cr3C2/50 CoCrAIY

\section{SERMATECH}

GGM-101

GGM-102

GGM-104

GGM-105 
Table I. - continued.

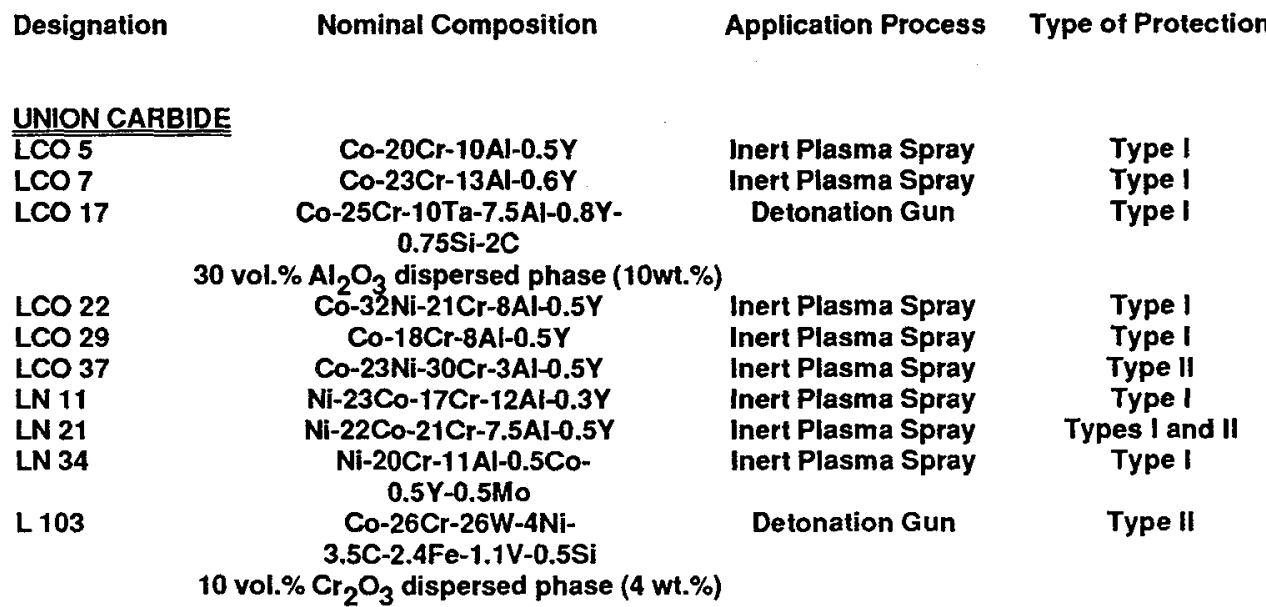

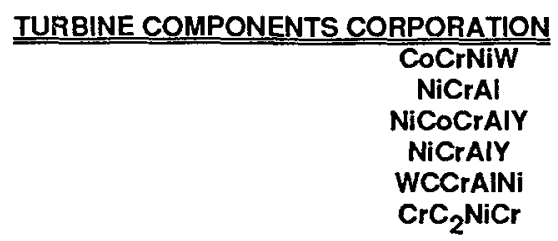

Thermal Spraying

Thermal Spraying

Thermal Spraying

Thermal Spraying

Thermal Spraying

Thermal Spraying

The ductile to brittle transition temperature (DBTT) of the overlay coating depends upon its composition. An increase in the $\mathrm{Al}$ or $\mathrm{Cr}$ content of the CoCrAlY coating tends to increase the DBT temperature. Therefore to improve ductility, coating aluminium levels below 12 wt.\% and sometimes as low as $5 \mathrm{wt} . \%$ are used. The addition of Ni to CoCrAlY coatings has been found to decrease the DBT temperatures. This is attributed to a higher DBT temperature of $\beta$-CoAl compared to $\beta$-NiAl which are the major constituents of the CoNiCrAlY and NiCoCrAlY coatings respectively. Control on the DBT temperature through the change in coating composition has allowed the design of coatings for specific applications where thermal fatigue damage is prevalent during service.

No single overlay coating can offer balanced oxidation and hot corrosion resistance as well as good mechanical properties under all service conditions. Therefore each overlay coating is designed to meet the demands of a given application.

The schematic diagram in figure 10 shows the effect of composition on the hot corrosion and oxidation resistance of several types of overlay and diffusion aluminide coatings.

The MCrAlY were first used in aircraft turbo engines and then in utility turbines or in marine aircraft engines. The continued development of these coatings has given rise to coating compositions as complex as Co-Ni-Cr-Al-Y-Ta or Ni-Co-Cr-Al-Hf-Si-Y for marine applications, for instance. The development of the LPPS or VPS deposition techniques, which allow alloys of an almost infinite range of compositions to be deposited, have resulted in an endless variety of coatings commercially available or in the stage of development. Table 1 shows a list of commercially available MCrAlY coatings which have been collected in the "Coating and High Temperature Corrosion" data bank. And this is only a small part of the total number of overlay coatings we have collected, so far, in the data bank. 


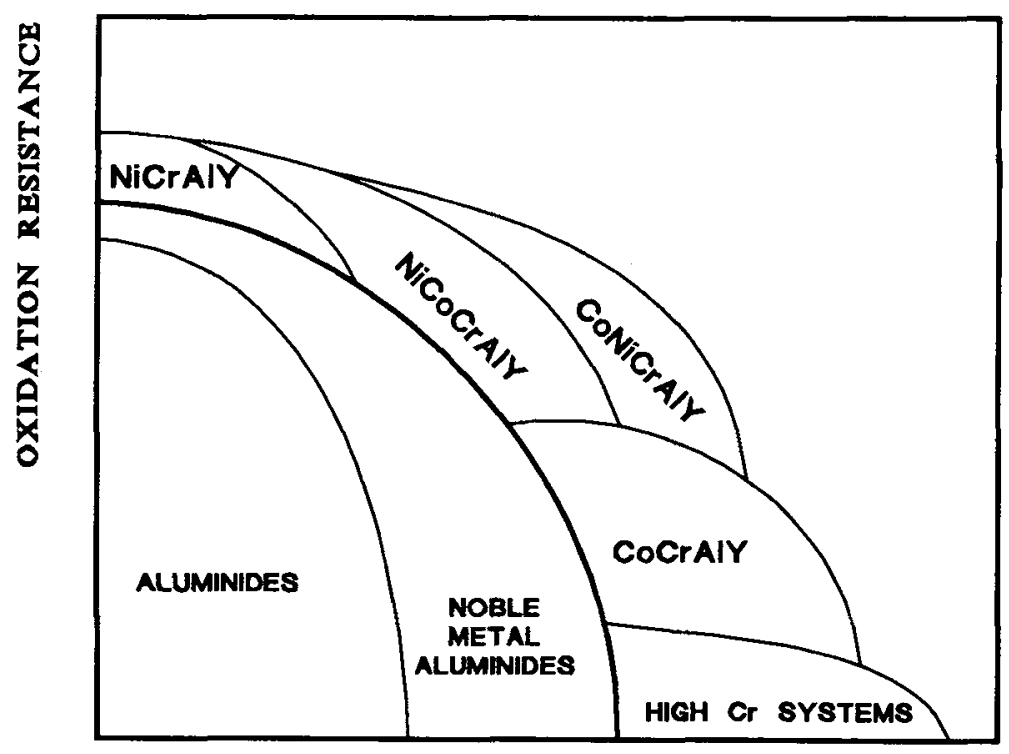

CORROSION RESISTANCE

Fig. 10. - Effect of composition on the hot corrosion and oxidation resistance of overlay and diffusion aluminide coatings (from A.J.A. Mom; National Aerospace Laboratory, The Netherlands - personal communication).

4.2 EB PVD THERMAL BARRIER [16, 17]. - The hot-corrosion (and oxidation) resistance of coated blades can be further improved by applying a coating which provides thermal insulation. This thermal-barrier coating (TBC) must be sufficiently thick, have a low thermal conductivity and high thermal-shock resistance, and have a high concentration of internal voids to reduce thermal conductivity to a value well below that of the bulk material. The temperature difference between the outer surface of a TBC and the outer surface of the underlying corrosion-resistant bond coat can be as high as $150^{\circ} \mathrm{C}$. In addition to reducing the temperature at the surface of the superalloy, these coatings also reduce thermal shock loads on the blades; rapid changes in ambient temperature are moderated and attenuated before they reach the substrate.

In electron-bean vacuum evaporation, the kinetic energies of accelerated free electrons are converted into thermal energy when they strike the material to be evaporated. EB evaporation offers several advantages which are particularly relevant for the deposition of relatively thick coatings in continuous operations :

- energy is transferred to the surface to evaporate only at isolated points or over restricted areas. Consequently, the evaporation rate can be varied over a large range -0.001 to $1.000 \mathrm{~nm} / \mathrm{s}$ - by varying beam power and power density. Vapour-bubble formation and associated damage caused to deposited coatings are significantly reduced;

- large amounts of coating materials can be evaporated by scanning the electron beam over melt pools with large surfaces;

- virtually all types of materials can be evaporated from water-cooled copper crucibles, while maintaining high purity levels;

- coating materials can be continuously fed to the crucible to facilitate continuous operation;

- multicomponent alloy coatings, having chemical compositions maintained within narrow 
tolerance ranges, can be deposited.

Two versions of the EB vacuum-evaporation method have potential for improving the properties of the coating deposited, particularly its density. In the so-called arc method, which has been successfully used to deposit hard coatings, a high proportion of evaporated particles is ionised. Thus, the vapour phase has a higher particle density, which results into denser coatings. Disadvantages of this method are low coating deposition rates and a tendency to form pinholes in the deposit due to "splash" caused by too high arc-power levels. Pinholes provide paths for corrodants to penetrate the coating and then damage the substrate.

A plasma-assisted evaporation method has even more potential for use in industrial-scale coating applications. In this process, positive ions are produced and accelerated using a supplementary electrode with application of a bias voltage to the parts. Coating condensation rates are comparable to those obtained in conventional vacuum evaporation, but the deposits are much denser and more resistant to hot-gas corrosion. The plasma-assisted technique has already been successfully used to deposit hard coatings on metal sheet, and its application to aircraft gas-turbine blades can be expected in the near future.

An example of a thermal-barrier coating is $\mathrm{ZrO}_{2}$ stabilised by an addition of about 7 wt.\% $\mathrm{Y}_{2} \mathrm{O}_{3}$. It is applied via the same procedure used for depositing corrosion-resistant coatings. The raw materials are $\mathrm{ZrO}_{2}$ and $\mathrm{Y}_{2} \mathrm{O}_{3}$. The oxygen deficit due to partial dissociation is compensated by adding metered amounts of oxygen during coating deposition. The crucibles, however, are much smaller than those used for evaporating metals. The evaporation temperatures of $\mathrm{ZrO}_{2}$ and $\mathrm{Y}_{2} \mathrm{O}_{3}$ are so high that the $\mathrm{EB}$ guns are not powerful enough to maintain a uniform temperature at the surface of a large-area melt pool.

Prior to depositing the $\mathrm{Y}_{2} \mathrm{O}_{3}$ - stabilised $\mathrm{ZrO}_{2} \mathrm{TBC}$, an insulating layer of $\mathrm{Al}_{2} \mathrm{O}_{3}$ is formed by diffusing and oxidising aluminium from the MCrAlY anti-corrosion bond coat. Growth of the $\mathrm{Al}_{2} \mathrm{O}_{3}$ film is self-limiting - it becomes extremely slow once it reaches a certain thickness.

This intermediate film provides additional oxidation resistance, as well as significantly enhancing adhesion of the subsequently applied TBC.

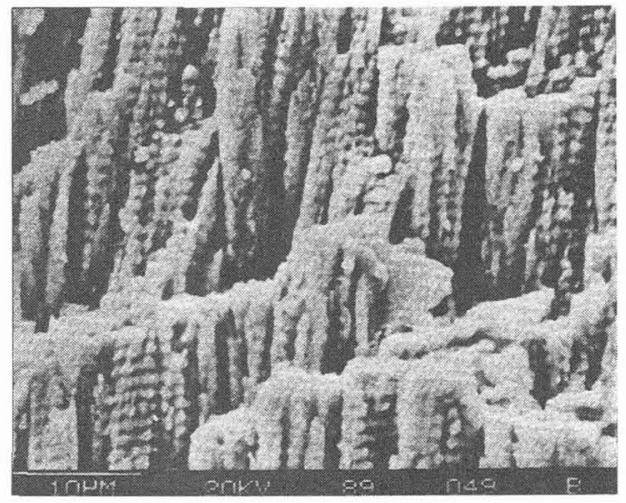

Fig. 11. - Scanning electron micrograph of a $\mathrm{Y}_{2} \mathrm{O}_{3}$ - stabilised $\mathrm{ZrO}_{2}$, thermal-barrier deposited by EB-PVD (from [17]). 
Figure 11 shows a scanning electron micrograph of an $\mathrm{Y}_{2} \mathrm{O}_{3}$ - stabilised $\mathrm{ZrO}_{2}$, thermal barrier coating deposited by EB vacuum evaporation on an MCrAlY-coated turbine blade [16]. The coating's dense, columnar structure makes it highly resistant to thermal shock. The coating is bonded via an alumina diffusion zone.

\section{The class of advanced coatings.}

Though the long list of advanced coatings given in the introduction of this paper, we will now only describe a few types of these coatings which involved exemplary design and technologic conception and which have open avenues of advanced technology, and may suggest further research on coating technology. These include :

- the chromium, noble metal, and rare earth modified aluminide coatings;

- an electrophoretic MCrAlY coating;

- and aluminides and composites aluminides coatings for titanium.

The list of advanced coatings given in the introduction is further covered by a number of papers in this Symposium, In particular, J. Steinmetz [18] has given an excellent and updated review on oxidation and protection by coatings of niobium base alloys.

\subsection{THE MODIFIED ALUMINIDE COATINGS.}

5.1.1 Chromium modified aluminide coatings. - Chromium can be present in diffusion aluminide coatings as a result of two processes.

5.1.1.1 Two step chromised aluminised coatings. - Chromium from the substrate is incorporated into the coating during the aluminising process. In this case the chromium is provided either by the substrate alloy or by additional chromium previously diffused into the alloy.

To prepare a chromium enriched aluminide coating of a higher level than would be available from substrate alloy a two-step chromising-aluminising process, involving prior enrichment of a surface layer by diffusion chromising, can be performed. This chromising may be carried out either with formation of an $\alpha$-Cr layer or with formation of a graded chromium enriched $\gamma$-phase layer without $\alpha$-Cr.

The structure and the formation mechanisms of chromaluminide coatings by graded vapour phase chromising and subsequent low and high activity aluminising have been described by Streiff and Boone [19]. And the structure of chromaluminide coatings formed by successive pack chromising and low and high activity pack cementation has been investigated by Godlewska and Godlewski [20].

5.1.1.2 Aluminium + chromium codeposited coatings. - Chromium may be incorporated in the aluminide coating from the coating medium by simultaneous deposition of chromium and aluminium in a single-step pack cementation process.

It has been generally stated that simultaneous deposition of aluminium and chromium on a nickel base alloy by pack cementation is difficult, if not impossible, because of the great difference in aluminium and chromium diffusivity in NiAl [21]. Marijnissen [22], however, has perfected a one step chromaluminising process that approximates such a co-deposition process but the coating microstructure which results contains layers of chromium and $\mathrm{NiAl}$ and can, therefore, hardly be characterised as belonging to the normal class of aluminide coatings. More recently, Rapp [23] has produced a coating with a Kanthal-like surface com- 
position, Fe-20Cr-4Al, by simultaneously chromising and aluminising iron or low-alloy steel by using a high activity $\mathrm{Cr} / \mathrm{Al}$ masteralloy and a rotating pack.

Special mention must be made at this point to the extensive programme developed at Ohio State University by Rapp and his group on halide activated pack codeposition. In addition to the chromium-aluminide coatings mentioned above they perfected a number of codeposition leading to doping of aluminide or chromium-aluminide coatings with rare earth reactive elements like $\mathrm{Y}$ or $\mathrm{Zr}$ or other elements like boron. They extended their codeposition technique to the formation of mixed coatings like silicon-chromium for iron and steels, or silicon-germanium for the refractory metals molybdenum, tungsten and niobium. This has opened a very promising future for the technology of modified coatings. Part of their results have been presented in the Plenary Lecture of Prof. Rapp in this Symposium.

5.1.2 Platinum modified aluminide coatings. - Significant improvements of the hot corrosion resistance of aluminide coatings in the high temperature range of hot corrosion (HTHC $900-1000^{\circ} \mathrm{C}$ ) are reported for platinum additions [24], but the effect in the low temperature regime (LTHC $600-750^{\circ} \mathrm{C}$ ) has little benefit and may even be detrimental [25]. Testing in both hot corrosion temperature ranges has shown a strong effect of coating structure. The platinum modified coatings develop a spectrum of structures derived from the archetypal two-zone and three-zone structures of standard aluminides, depending on aluminising treatments and platinum deposit heat treatments prior to aluminisation of the alloys [26].

The role of platinum in the aluminide solid solution has been evidenced. It was found that, in the Pt-aluminide systems, platinum diffusional processes behave in a manner similar to $\mathrm{Ni}$ in NiAl where stoechiometry exerts a strong effect. Thus $\mathrm{Pt}$ is apparently relatively immobile in the Al-rich NiAl phase and highly mobile in Ni-rich NiAl. The differences in hot corrosion can be ascribed to the differences in microstructures of the various tested systems. Recent progress has been made in the production of platinum modified aluminide coating by using a vapour phase deposition technique [27].

5.1.3 Chromium modified platinum aluminide coatings. - More recently, an evaluation of the potentially beneficial effect of combined chromium and platinum addition has been made by Boone and Shankar [28].

Chromium modified platinum aluminide coatings have been prepared by either : 1) electroplate platinising followed by pack chromising and subsequent low activity aluminising; or 2) pack chromising, followed by electroplate platinising and finally low activity aluminising.

The Pt-Cr-Al coating exhibits a three-zone structure similar to a low activity type platinum modified aluminide coating. The Cr-Pt-Al coating has a somewhat more complicated structure. There is a thick high density surface layer of $\mathrm{PtAl}_{2}$ with a small volume fraction of $\alpha$ chromium. This structure with a high level of platinum and chromium in a limited region of the coating, suggests an initial inward diffusion of aluminium which entraps the platinum and chromium followed by reduced $\mathrm{Al}$ activity and subsequent nickel diffusion. These coatings combining the chromium beneficial effect with the platinum modification of aluminide coatings have shown good type 2 hot corrosion resistance and are in production for protection of aeroengine blades.

5.1.4 Palladium modified aluminide coatings. - It has been frequently reported that palladium shows very poor high temperature corrosion resistance and that the behaviour of palladium modified aluminide coatings is worse than that of the platinum modified coatings. Alpérine and Steinmetz [29] have recently demonstrated that this counter performance could be ascribed to the hydrogen embrittlement of the coating during its deposition. A palladium modified coating has been perfected by two different processes which prevent gas intake during 
the aluminising process :

1) by replacing the pure palladium pre-deposit in which hydrogen is highly soluble by a palladium $+\mathrm{M}$ alloy ( $\mathrm{M}$ being a transition metal like $\mathrm{Ni}$, Co or $\mathrm{Cr}$ in which hydrogen is far less soluble);

2) by applying onto the substrate a duplex pre-deposit made of two metallic layers: a pure palladium underlayer and a top layer of metal $M$. After diffusion annealing the outer zone of the pre-deposit becomes a Pd-M alloy rich in metal $\mathrm{M}$ which acts as a diffusion barrier against hydrogen. 12.

The microstructure of this palladium modified aluminide coating is presented in figure

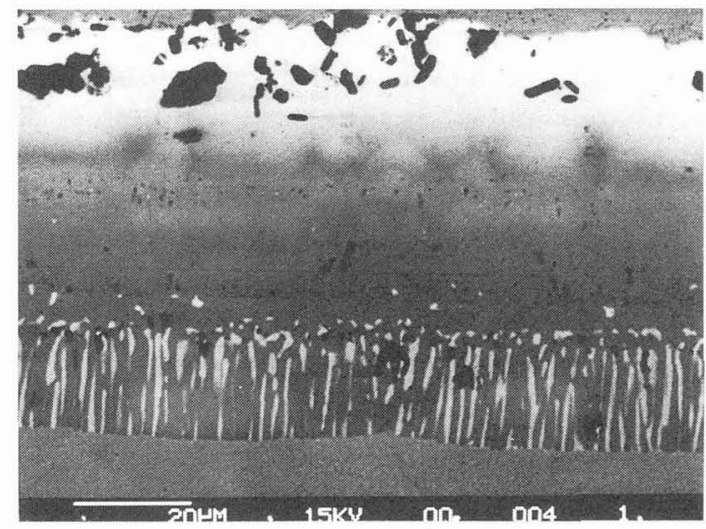

Fig. 12. - Microstructure of a palladium modified aluminide coating (by courtesy of P. Steinmetz; Université de Nancy, Fr.).

5.1.5 Yttrium and other R.E. modified aluminide coatings. - It is well known that yttrium addition to alloys improves the oxidation resistance by improving the adherence of the oxide scale. It was therefore a trivial idea to try to improve aluminide coating oxidation resistance by addition of yttrium or other reactive elements to the straight aluminide. As already mentioned $\mathrm{Wu}$ et al. have perfected an yttrium-aluminide coating by a first slurry yttrising step followed by a pack aluminising second step. They reported improved hot corrosion resistance in a crucible $\mathrm{NaCl}+\mathrm{Na}_{2} \mathrm{SO}_{4}$ corrosion test over a straight aluminide tested in the same conditions.

Kim et al. [30] have perfected an yttrium modified coating by $\mathrm{Y}$ ion platting after pack aluminising. They observed first that, because of unstability of ion-plated Y during subsequent aluminising, the two step $\mathrm{Y}$ ion platting + aluminising was not possible. After $\mathrm{Y}$ ion platting the uniformity of the $\mathrm{Y}$ deposition was dependent on the coating conditions. The high activity aluminide coating resulted in better $\mathrm{Y}$ uniformity than the low activity coating. Hot corrosion improvement was reported due to improvement in the $\mathrm{Al}_{2} \mathrm{O}_{3}$ scale adherence and to substantial reduction of $\mathrm{Al}$ depletion in the aluminide coating layer.

$\mathrm{Li}$ et al. [31] perfected a series of coatings with rare earth oxide dispersions. These include $\mathrm{Y}_{2} \mathrm{O}_{3}, \mathrm{La}_{2} \mathrm{O}_{3}, \mathrm{Gd}_{2} \mathrm{O}_{3}$ and ceria. The oxides were electro-deposited and subsequently pack 
aluminised. It was found that as long as the level of rare earth oxide addition is kept at a low level these coatings showed improved oxidation resistance as compared to simple aluminide coatings.

Finally, one of our students, N'gandu Muamba, has demonstrated in his PhD thesis [32], that aluminide coatings modified by hafnium diffusing from substrate have improved cyclic oxidation resistance when compared to simple aluminides deposited on alloys without hafnium. This might be the avenue for tomorrow's inexpensive improved aluminide coatings.

5.2 Electrophoretic MCrAl COATING. - One of the major drawbacks of the vacuum plasma spraying or low pressure plasma spraying processes is that these are line-of-sight processes and do not allow the coating of components which have complex shapes. Alternative deposition processes for these MCrAlY alloys such as electrolytic codeposition or electrophoresis have been developed, which claim technical and economical advantages.

A process was perfected by Morbioli [33], at SNECMA (Fr.) in which CoNiCrAlYTa alloy powders with particles less than $40 \mu \mathrm{m}$ are deposited by electrophoresis on the component to be coated and subsequently vapour phase aluminised. The end MCrAlY coating obtained by this process is shown in figure 13 along with the porous electrophoretic deposit. With adequate electrode geometry, components with complex shape such as turbine vanes or cooled blades can be uniformly coated. These coatings exhibit hot corrosion resistance comparable with that of LPPS coatings (Fig. 14).

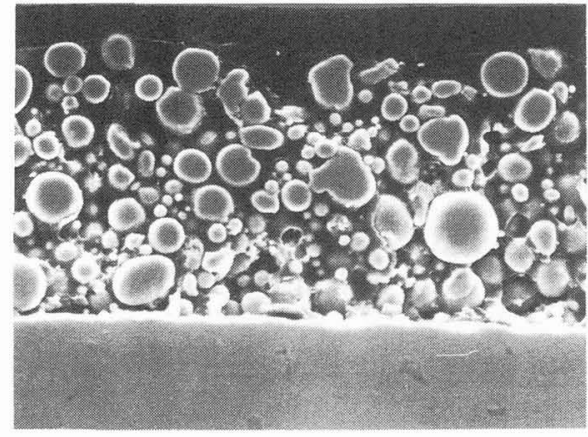

a)

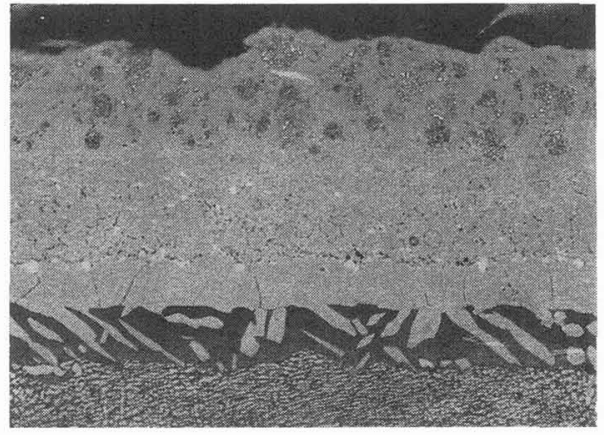

b)

Fig. 13. - Microstructure of Snecma's C3A overlay coating : a) the electrophoretic MCrAlY deposit; b) the vapour phase aluminising consolidated coating (by courtesy of R. Morbioli; SNECMA, Fr.).

\subsection{ALUMINIDE COATINGS FOR TITANIUM AND TITANIUM ALLOYS.}

5.3.1 Aluminide coatings on unalloyed titanium. - For several decades, titanium and titanium alloys have been potential materials for aeronautic and space turboengines or airframe structures. Since they were first introduced as J57 Turbojet rotors in 1954, titanium alloys have played a key role in improving gas turbine performance. Titanium and titanium alloys combine high strength with medium density and have been used in aircraft engines and structures owing to their high strength/weight ratio. However, extensive utilisation remained hindered by an excessive reactivity, especially in high temperature environments. 
- Hot corrosion behaviour (IN 100 substrate)

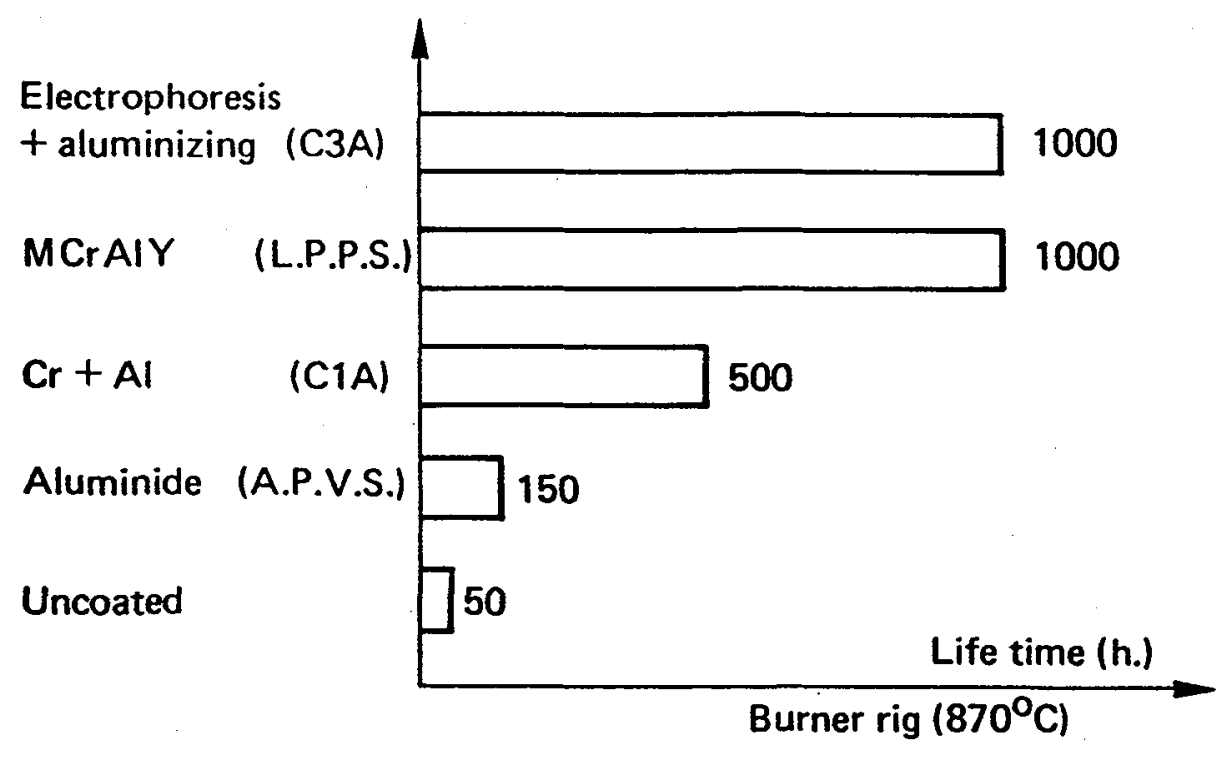

Fig. 14. - Hot corrosion resistance of this MCrAlY Coating (from R. Morbioli; SNECMA, Fr. - personal communication).

Early studies on oxidation of unalloyed titanium started in the late 50's . Specific features of unalloyed and alloyed titanium oxidation such as formation of a stratified scale have been extensively investigated. The first attempts to improve the oxidation resistance of titanium were by alloying it with numerous addition elements. For example, the increase of the working temperature of turbines has resulted from a series of $\mathrm{Ti}$ alloys containing $\mathrm{Al}, \mathrm{Zr}, \mathrm{V}, \mathrm{Sn}$, $\mathrm{Mo}$ and Si [34]. Alloy development and processing innovations over the years have provided a range of reliable titanium alloy which are in current use. These alloys offer the opportunity of substantial weight reductions compared to nickel- and iron-base superalloys, allowing reductions in airframe weight and increased thrust/weight ratios of gas turbines.

Titanium alloys, however, suffer from limitations in damage tolerance, creep strength and fire resistance at high temperatures. The need to develop new materials which can overcome these limitations has resulted in a number of programmes over the last ten years. Candidate materials should be lighter than nickel-base superalloys and possess roughly the same mechanical properties and oxidation resistance as the superalloys in current use.

Currently, the most suitable materials to meet this demand are alloys based on the titanium aluminides, viz. $\alpha$-2 titanium based on $\mathrm{Ti}_{3} \mathrm{Al}$ and $\gamma$ alloys based on TiAl. Titanium aluminides can replace superalloys in several engine parts: such components as compressor blades and turbine disks have been successfully fabricated and tested.

However, titanium aluminides suffer from low ductility and toughness at ambient temperature, which along with poor formability, appears to be one of the major obstacles to an extensive utilisation. Although $\gamma$ alloys have higher oxidation resistance than $\alpha-2$ alloys, they are still not adequate for very high temperature applications. It appears that the maximum application temperature for titanium aluminides is determined by oxidation resistance rather than creep or strength retention. Improvement in oxidation resistance is therefore a key fac- 
tor in increasing operating temperature.

Another approach to protect titanium alloys from high temperature oxidation is to coat them with a compound which has a higher oxidation resistance than the base materials. Contrary to the wealth of papers which have been published on the coatings for superalloys, especially $\mathrm{NiAl}$, and CoAl on respectively $\mathrm{Ni}$-base and Co-base-alloys, there are only very few published works on the protection of titanium by coatings. The very first attempt to protect titanium by a coating is due to Abba $e t a l$. in 1979 [35]. They perfected a silicide coating by depositing silicide layers on unalloyed titanium by decomposition of silane $\left(\mathrm{SiH}_{4}\right)$ on heated titanium ribbons. This coating resulted in a marked improvement in oxidation resistance of the coated materials. In 1980, Poize [36] and Streiff and Poize [37] described the first titanium aluminide coating which was deposited by pack aluminising.

After chemical etching or anodic coloration the aluminised specimens showed two types of coatings, depending on aluminising temperature. Up to $800^{\circ} \mathrm{C}$ the coating was formed by a thick $\mathrm{TiAl}_{3}$ scale over a thin underlayer too thin to be identified (Fig. 15). This structure remained unchanged for very long aluminising duration, e.g. up to $120 \mathrm{~h}$ at $760^{\circ} \mathrm{C}$ without appreciable growth of the underlayer.
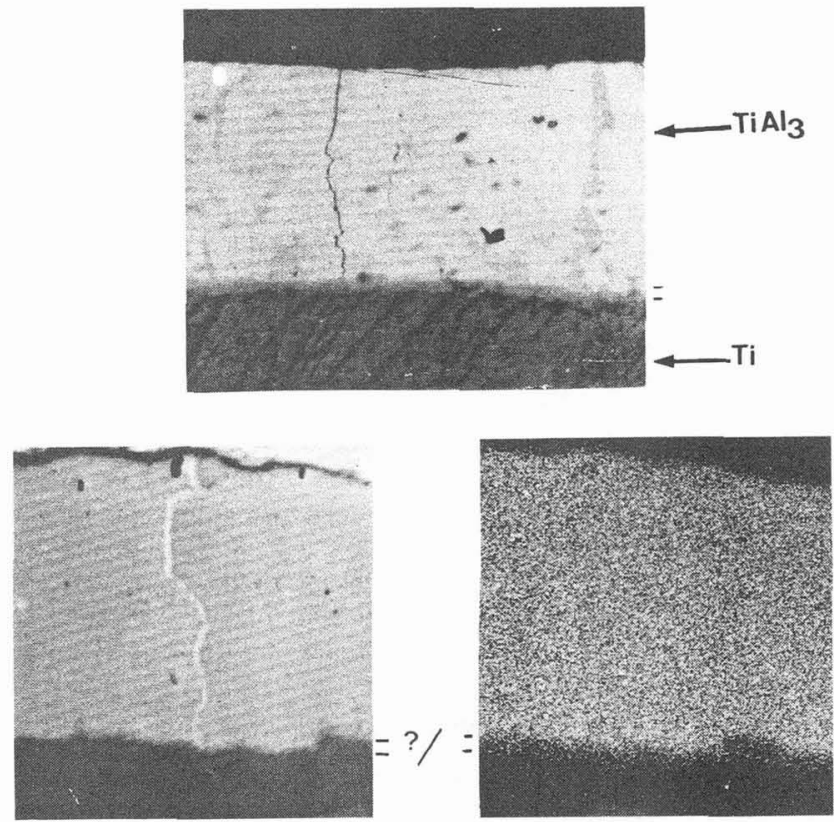

Fig. 15. - Microstructure of the low temperature titanium aluminide coating.

At $850^{\circ} \mathrm{C}$ and above the coating exhibited the 4 phases existing at these temperatures in the $\mathrm{Ti}$-Al phase diagram: $\mathrm{TiAl}_{3}, \mathrm{TiAl}_{2}, \mathrm{TiAl}$ and $\mathrm{Ti}_{3} \mathrm{Al}$ in superposed layers with unequal thickness (Fig.16). The three internal layers reached distinct measurable thicknesses at about $9 \mathrm{~h}$ at $850^{\circ} \mathrm{C}$ and after $4 \mathrm{~h}$ at $900^{\circ} \mathrm{C}$.

Microprobe analysis confirmed these coating structures by identification of the thick $\mathrm{TiAl}_{3}$ scale in both types (Fig. 17). The under-layers of the high temperature coating were identi- 


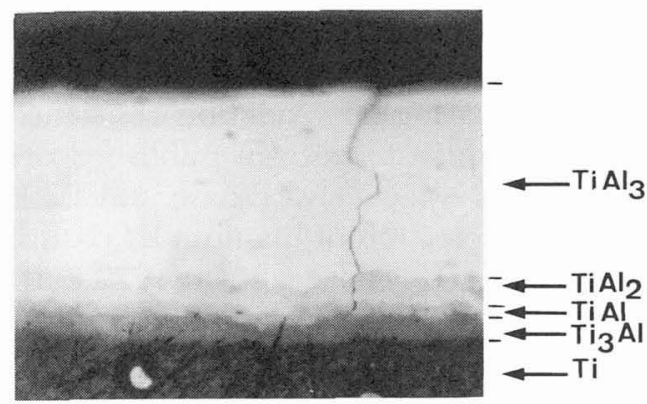

Fig. 16. - Microstructure of the high temperature titanium aluminide coating.
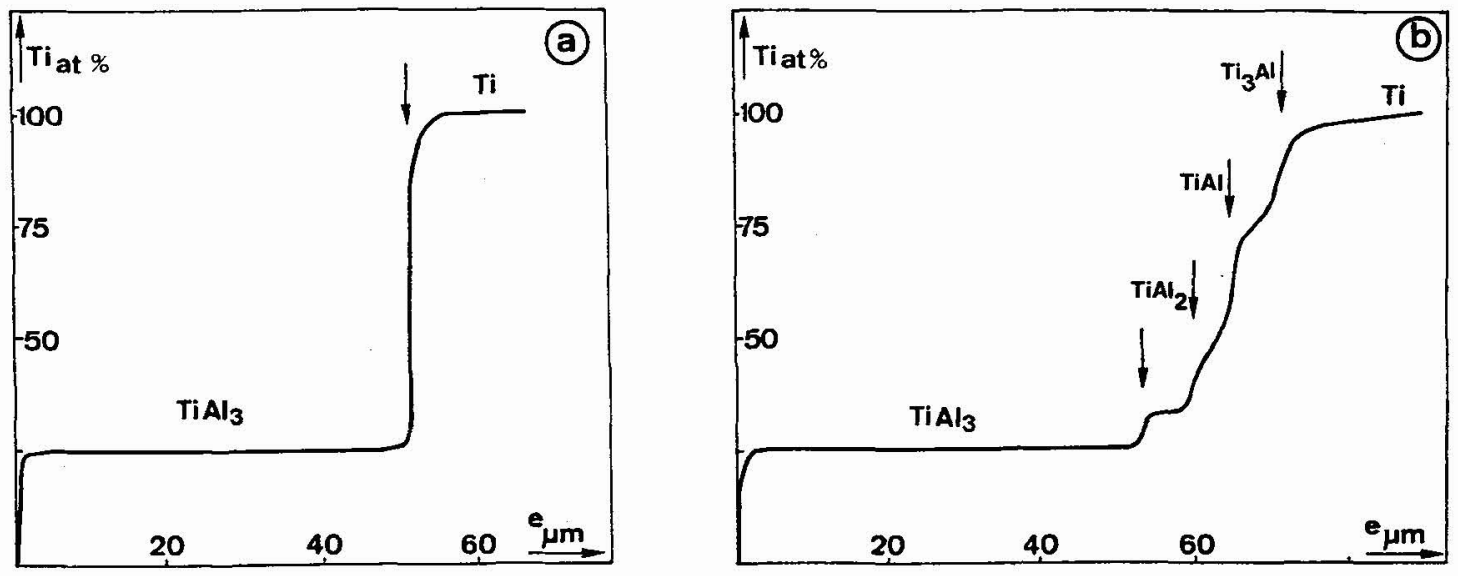

Fig. 17. - Microprobe analysis of: a) the low temperature titanium aluminide coating; b) the high temperature coating.

fied by surface X-ray diffraction after stepwise removal of the outer layers.

Transverse fissuring occurred in almost all the coatings (see Figs. 14, 15). Its occurrence, however, seemed independent of the aluminising parameters leading to coating quality, even of the temperature. These fissures probably formed during the cooling of the specimens at the end of the aluminising runs; they all arose, indeed, at the coating outer surface and penetrated the coating following grain boundaries. Moreover, they crossed the interfaces of the under-layers in the high temperature coating without modifying them, which confirms that they do not form during the cementation process. Nevertheless, this titanium aluminide coating showed remarkable improvement in isothermal oxidation resistance [38]. Up to now, as far as we know, only two other papers have been published in the open literature on the development of aluminide coatings on unalloyed titanium [39, 40]. These coatings present essentially the same structure as the one perfected by Poize. However, in the past years there has been a great interest on the development of titanium aluminide coatings to protect $\gamma$ and $\alpha-2$ titanium aluminide alloys. 
5.3.2 Aluminide coatings on titanium aluminide alloys. - Smialek et al. [41] have studied the cyclic oxidation of aluminide coatings on an $\alpha-2+\mathrm{Nb}$ titanium aluminide alloy. They produced a pack aluminide coating at 800 and $1038^{\circ} \mathrm{C}$. The primary coating phase was $\mathrm{TiAl}_{3}$ at both 800 and $1038^{\circ} \mathrm{C}$. Pack temperature did not produce any obvious differences in pack behaviour. Other pack parameters were however quite important in determining the level of aluminium pickup. Higher levels of aluminium source material and longer coating times both resulted in greater coating weights. $\mathrm{NaF}$ also was a more efficient activator than $\mathrm{NaCl}$.

All the coatings showed a considerable degree of protection. The $200 \mathrm{~h}$ weight gain ranged from about 0.5 to $2.5 \mathrm{mg} / \mathrm{cm}^{2}$. The weight change curves all showed positives slopes, which is an indication of minimal scale spallation. By comparison, the uncoated substrate lost 4 $\mathrm{mg} / \mathrm{cm}^{2}$ after $100 \mathrm{~h}$ oxidation and spallation was quite apparent. Bulk $\mathrm{TiAl}_{3}$, on the other hand, showed a rapid weight gain in the first $100 \mathrm{~h}$, followed by extremely slow scale growth kinetics. The main result of this study was that thicker coatings offered less oxidation protection. The wide variation in pack parameters mainly resulted in variation of aluminium pickup, which in turn was found to have an effect on oxidation, thicker coatings producing greater weight gain in oxidation. This is believed to be caused by the severity of the coating cracks already observed in the coating on unalloyed titanium by Poize and others.

5.4 COMPOSITE ALUMINIDE COATINGS FOR TITANIUM. - A special class of coatings has been perfected to improve titanium resistance to erosion/corrosion environments. These coatings combine the good erosion resistance of $\mathrm{TiN}$, or $\mathrm{TiB}_{2}$, or $\mathrm{TiC}$ and the good oxidation resistance of $\mathrm{TiAl}_{3}$.

5.4.1 TiN/TiAl 3 composite coating. - The first coating of this class was prepared by associating the titanium nitride TiN and the aluminide $\mathrm{TiAl}_{3}$ [42]. Two preparation methods were used: first aluminising (by pack cementation) followed by nitriding (by nitrogen) or nitriding before aluminising. The coatings obtained in the two cases had different compositions but very similar properties: viz. microhardness between 1000 and 1400 VICKERS and an oxidation resistance in oxygen almost identical to $\mathrm{TiAl}_{3}$ below $850^{\circ} \mathrm{C}$. For higher temperatures the coating degraded rapidly either by destruction of $\mathrm{TiAl}_{3}$ (by formation of sub-aluminides) or by the formation of the ternary compound $\mathrm{Ti}_{2} \mathrm{AlN}$.

5.4.2 $\mathrm{TiB}_{2} / \mathrm{TiAl}_{3}$ composite coating. - Coatings associating the titanium aluminide $\mathrm{TiAl}_{3}$ and the titanium boride $\mathrm{TiB}_{2}$ were obtained in a two step process [43], the boronising preceding the aluminising. These coatings showed a microhardness of about 1500 Vickers and their behaviour in oxidation, though not as good as pure $\mathrm{TiAl}_{3}$, was much better than that of $\mathrm{TiB}_{2}$. These coatings are a good compromise between purely wear-resistant or purely oxidationresistant coatings.

5.4.3 $\mathrm{TiC} / \mathrm{TiAl}_{3}$ composite coating. - Finally, coatings with $90 \mathrm{~mol} \% \mathrm{TiC}$ and $10 \mathrm{~mol} . \% \mathrm{TiAl} 3$ were prepared by a two step process, involving first carburisation by gaseous methane and then fluoride pack aluminising [44]. The microhardness of these coatings is much higher than that of pure $\mathrm{TiAl}_{3}$, and their oxidation resistance at temperature below $800^{\circ} \mathrm{C}$ is better than that of pure TiC.

5.4.4 Remarks on these composite coatings. - These coatings cannot be ranked in the class of high temperature protective coatings. The base material different from TiAl is more usually used as hard coating. Titanium boride, nitride and carbide have inherent poor oxidation resistance. However, associating them with the titanium aluminide has demonstrated that 
they achieve a reasonable good compromise between resistance to wear and resistance to oxidation. It was therefore worth presenting them in this review on high temperature corrosion resistant coatings.

\section{Summary.}

In this paper we have reviewed the present state of the coating technology and of protection of materials. A classification of the presently available coatings has been proposed which include classical coatings, modern coatings and advanced coatings. The state of the art of the diffusion coatings (which belong to the classical class) processing has been reviewed and the latest achievements in aluminide, and modified aluminide coatings described. The most recent progress in deposition of Thermal Barrier Coatings (which belong to the modern class), viz. EB-PVD technology, have been reported. To finish a series of advanced coatings have been reviewed. These represent the latest achievement and progress in today's coating technology.

\section{References}

[1] STREIFF R., High Temperature Corrosion 2, R. Streiff, J. Stringer, R.C. Krutenat, M. Caillet Eds. (Elseveier Science Publ., Barking, U.K., 1989) pp. 693-696; Mat. Sci. Eng. A121 (1989) 693-696.

[2] STREIFF R., KOMORNICKI S., Surface and Coatings Technology 50 (1992) 263-269.

[3] STRINGER J., Surf. Eng., NATO ASI Series, R. Kossowski and S.G. Singhal Eds. (Martinus Nijhoff Publ., Dordrecht, NL, 1984) pp. 561-587.

[4] GOWARD G.W., J. Engin. Gas Turbine 108 (1986) 421-425.

[5] PetTit F.S., Meier G., Superalloys -1984, M. Gell, C.S. Kortowich, R.H. Bricknell, W.B. Kent and J.F. Radavich Eds. (The Metallurgical Soc. Publ. Warrendale, PA, 1984) pp. 651-687.

[6] GOWARD G.W., BOONE D.H., Oxid. Met. 3 (1971) 475-495.

[7] GaUje G., Morbioli R., High Temperature Protective Coatings, S.C. Singhal Ed. (AIME Publ. Warrendale, PA, 1982) pp. 13-26.

[8] Patnaik P.C., Mater. Manufact. Processes 4 (1989) 133-152.

[9] YOUNG S.G., DEADMORE D.L., NASA report TM-79178 (July 1979).

[10] WANG F, LOU H., BaI L., WU W., High Temperature Corrosion 2 . R. Streiff, J. Stringer, R.C. Krutenat, M. Caillet Eds. (Elseveier Science Publ., Barking, U.K., 1989) pp. 387-389; Mat. Sci. Eng. A121 (1989) 387-389.

[11] BORZILlO A.R., CAHN W.C., Trans. ASM 62 (1969) 729.

[12] DenNer S., KIM Y., High Temperature Protective Coatings, S.C. Singhal Ed. (AIME Publ. Warrendale, PA, 1982) pp. 233-250.

[13] Bangaru N.V., Krutenat R.D., J. Vac. Sci. Technol. B 2 (1984) 806-815.

[14] KUnG S.C., RaPP R.A., Surf. Coating Tech. 32 (1987) 41-56;

KUNG S.C., RAPP R.A., J. Electrochem. Soc. 135 (1988) 731.

[15] Tortorelli P.F., Devan J.H., Mater. Sci. Eng. A153 (1992) 573-577.

[16] MEIER S.M., GUPTA D.K., SHEFFLER K.D., J. Metals (march 1991) pp. 50-53.

[17] Lämmermann H., Kienel G., Adv. Mater. Proc. 12 (1991) 18-23. 
[18] STEINMETZ J,, VILASI M., RoQUes B., this conference.

[19] STREIfF R., BOONE D.H., Reactivity of Solids, P. Barret, L-C. Dufour Eds. (Elsevier Publ. Amsterdam, NL, 1985) pp. 195-197.

[20] GodlewsKa E., GodLEWSKi K., Oxid. Met. 22 (1984) 117-131.

[21] Walsh P.N., 4th Chemical Vapour Deposition, G.F. Wakefield and J.M. Blocher Jr. Eds. (The Electrochemical Soc., Publ. Princeton, NJ, 1983) pp. 147-168.

[22] MariJnissen G., High-Temperature Protective Coatings, S.C. Singhal Ed. (The Metallurgical Soc. Publ. Warrendale, PA, 1984) pp. 27-35.

[23] RAPP R.A., WANG D., WEISERT T., High Temperature Coatings, M. Khobaib and R.C. Krutenat Eds. (The Metallurgical Soc., Publ. Warrendale, PA, 1987) pp. 131-141.

[24] Deb P., BoONE D.H., STReiff R., J. Vac. Sci. Technol. A3 (1985) 2578-2581.

[25] Boone D.H., Deb P., STReiff R., Surface Modifications and Coatings, R.D. Sisson Jr. Ed. (American Soc. Metals, Publ. Metals Park, Oh, 1986) pp. 143-159.

[26] STreiff R., Boone D.H., Purvis L.J., Surface Engineering NATO ASI Series, Kossowski and Singhal Eds. (Martinus Nijhoff Publ. Dordrecht, NL, 1984) pp. 469-482.

[27] BOONE D.H., SMITH J.S., Proceed. International Symposium on High Temperature Corrosion and Protection, Shenyang June 1990, China, Guan H., Wu W., Shen J., Li T. Eds. (Liaoning Science and Technology Pub, PRG, 1991) pp. 267-277.

[28] Dust M.W., Deb P., BoOne D.H., ShankaR S., ASME paper 86-GT-291 (1986) pp. 1-7.

[29] Alperine S., Steinmetz P., Friant-Constantini A., Josso P., Surf. Coating Technol. 43/44 (1990) 347-358.

[30] KIM K.Y., JUN J.H., LEE J.K., this conference.

[31] LI T.F., HE H., Proceed. International Symposium on High Temperature Corrosion and Protection, Shenyang June 1990, China, Guan H., Wu W., Shen J., Li T. Eds. (Liaoning Science and Technology Pub, PRC, 1991) pp. 79-84;

LI T.F., MA X.Q., ibid. pp. 85-89.

[32] N'GANDU MUAMBA J.M., Thèse de Doctorat d'Etat, Marseille (juillet, 1993).

[33] Morbioli R. High Temperature Corrosion 2, R. Streiff, J. Stringer, R.C. Krutenat, M. Caillet Eds. (Elseveier Science Publ., Barkin, UK, 1989) pp. 373-378; Mat. Sci. Engin. A121 (1989) 373-378.

[34] Champin B., Graaff L., Armand M., Beranger G., Coddet C., J. Less Comm. Met. 69 (1980) 163.

[35] Abba A., Galerie A., Caillet M., Ann. Chim. Sci. Mater. 4 (1979) 15-26.

[36] Poize S., Thèse d'Université, Marseille (Fr.) (July, 1980).

[37] STREIfF R., POIzE S., GVD 8, Blocher, Vuillard and Wahl Eds. (The Electrochem. Soc. Publ. Pennington, NJ, 1981) pp. 525-532.

[38] STreiff R., Poize S., High Temperature Corrosion, R.A.Rapp Ed. (NACE Publ. Houston, TX, 1983) pp. 591-597.

[39] Subrahmanyam J., ANNAPurna J., Oxid. Met. 26 (1986) 275.

[40] TAKeI A., ISHIdA A., ONODERA H., Interfinish 88, Proceed. 12th World Congress Surf. Finishing (A.I.T.E. Paris, 1988) vol. 3, pp. 983-989;

TAKei A., Ishida A., Corrosion Control, Proceed. 7th Asian Pacific Corr. Control Conf. (Inter Acad. Publ., 1991) vol.2, pp. 718-724.

[41] SMialeK J.L., GedWill M.A., BRindley P.K., Scr. Met. Mater. 24 (1990) 1291-1296.

[42] Kabbaj M., Galerie A., Caillet M., J. Less Comm. Met. 108 (1985) 1-21.

[43] Kabbaj M., Galerie A., Caillet M., J. Less Comm. Met. 120 (1986) 21-33.

[44] Kabbaj M., Galerie A., Caillet M., J. Less Comm. Met. 115 (1986) 217-224. 